\title{
Komparasi Geokimia Batuan Gunung Api Kuarter dan Tersier di Tepian Selatan Lampung
}

\section{Geochemical Comparison between Quaternary and Tertiary Volcanic Rocks in the Southern Edge of Lampung}

\author{
Ronaldo Irzon* \\ Pusat Survei Geologi, Kementerian ESDM \\ Jl. Diponegoro 57 Bandung, Indonesia, 40115 \\ *E-mail: ronaldoirzon18@gmail.com
}

Naskah diterima: 14 Oktober 2020, direvisi: 21 Oktober 2020, disetujui: 29 Oktober 2020

DOI: 10.17146/eksplorium.2020.41.2.6053

\begin{abstract}
ABSTRAK
Keterdapatan batuan gunung api di Sumatra diakibatkan oleh penunjaman Lempeng Samudra India-Australia ke bawah Lempeng West Sumatra sejak Eosen. Tanggamus adalah kabupaten di ujung selatan Lampung dengan keterdapatan beberapa unit batuan gunung api berumur Tersier maupun Kuarter. Studi ini bertujuan untuk membandingkan komposisi geokimia batuan gunung api Tersier Formasi Hulusimpang dengan batuan gunung api Kuarter Gunung Tanggamus. Perangkat XRF dan ICP-MS dimanfaatkan untuk mengetahui kadar oksida utama, unsur jejak, dan unsur tanah jarang pada penelitian ini. Berdasarkan karakter geokimia, sampel dari Formasi Hulusimpang adalah batuan gunung api kalk-alkali, metalumina hingga peralumina, dan dalam rentang trakiandesit basaltik hingga riolit. Sampel batuan gunung api berumur Kuarter berada pada rentang kadar silika yang lebih sempit dan cenderung metalumina. Studi ini membuktikan bahwa kedua kelompok batuan berasal dari magma yang sama, tetapi dengan kontaminasi kerak selama diferensiasi. Proses pembentukan yang berbeda pada kedua kelompok batuan diperjelas oleh derajat kemiringan kurva diagram laba-laba UTJ dan jenis anomali Eu.
\end{abstract}

Kata kunci: batuan gunung api, geokimia, Formasi Hulusimpang, Tanggamus

\begin{abstract}
The presence of volcanic rocks in Sumatra is due to the subduction of the Indian-Australian Ocean Plate under the West Sumatra Plate since the Eocene. Tanggamus Regency situated at the southern edge of Lampung with the occurrence of several Tertiary and Quaternary volcanic rock units. The aim of this study is to compare the geochemical composition of Tertiary volcanic rocks from the Hulusimpang Formation and Quaternary volcanic rocks from Mount Tanggamus in the Tanggamus Regency. XRF and ICP-MS devices were used to determine the compositions of major oxides, trace elements, and rare earth elements in this study. Based on geochemical characters, samples from the Hulusimpang Formation are calc-alkaline volcanic rocks, metaluminous to peraluminous, and in the basaltic trachyandesite to rhyolite ranges. Quaternary samples are in a narrower range of silica content and tend to be metaluminous. This study proves that the two rock groups originate from the same magma but with crustal contamination during differentiation. The two volcanic should experience through different formation processes based on the slope of the heavy-REE and the type of Eu anomaly.
\end{abstract}

Keywords: volcanic rocks, geochemistry, Hulusimpang Formation, Tanggamus 


\section{PENDAHULUAN}

Komposisi geokimia banyak bermanfaat untuk menjelaskan fenomena kebumian. Proses diferensiasi magma (magma differentiation) yang dipengaruhi oleh faktor derajat lelehan sebagian (partial melting), fraksionasi kristal (crystal fractionation), pencampuran magma (magma mixing), dan kontaminasi dapat dicirikan berdasarkan karakter geokimia [1-4]. Kondisi tektonik pembentukan batuan dapat diklasifikasikan melalui rasio beberapa konsentrasi unsur jejak, unsur tanah jarang (UTJ), maupun isotop [5-7]. Mineralisasi logam tertentu juga sering terjadi pada batuan dengan karakter spesifik, seperti Ni-Co cenderung pada batuan rendah $\mathrm{SiO}_{2}$ (ultra mafik-mafik) dan $\mathrm{Sn}-\mathrm{W}$ pada batuan tinggi $\mathrm{SiO}_{2}$ (felsik) dapat dijelaskan berdasarkan kecenderungan karakter geokimia seperti terdapat pada penelitian terdahulu [8-11]. Tipikal batuan yang terdapat pada sekitar aliran sungai dapat ditelusuri dengan studi geokimia sedimen aliran [12, 13]. Derajat kontaminasi logam berat pada wilayah bekas penambangan dapat ditentukan melalui perbandingan komposisi sedimen terhadap nilai ambang batas yang telah ditetapkan [14, 15]. Oleh sebab itu, komposisi geokimia batuan gunung api dapat menjelaskan proses pembentukan maupun korelasi antar batuan di sekitarnya.

Sumatra pada masa kini adalah penggabungan Lempeng West Sumatra dan Sibumasu yang terjadi saat Trias [16, 17]. Kedua lempeng tersebut kini terpisah oleh garis imajiner yang disebut Medial Sumatra Tectonic Zone (MSTZ). Pulau dengan luas $>470.000 \mathrm{~km}^{2}$ tersebut adalah pulau terbesar keempat dan pernah menjadi daerah dengan aktifitas gunung api terbesar di dunia [18, 19]. Aktifitas vulkanik tadi tergambar oleh deretan Bukit Barisan yang terbentuk akibat penunjaman Lempeng Samudra India-
Australia ke bawah Lempeng West Sumatra sejak Eosen $[6,20]$. Penunjaman yang masih berlangsung hingga kini terjadi dengan kecepatan 5-6 cm/tahun dan berarah $\mathrm{N} 23^{\circ} \mathrm{E}$ $[21,22]$. Indikasi mengenai ketidakseragaman sudut penunjaman antara bagian utara, tengah, dan selatan Sumatra berdasarkan sebaran batuan gunung api telah dijelaskan oleh peneliti terdahulu [23].

Batuan gunung api dengan rentang umur Tersier hingga Kuarter tersebar dari utara hingga selatan Pulau Sumatra (Gambar 1). Studi sebelumnya menjelaskan bahwa batuan gunung api di bagian selatan Sumatra terindikasi terbentuk pada tiga kondisi tektonik berbeda, yaitu busur kepulauan (island arc), tepi benua aktif (active continental margin, ACM), dan antara lempeng benua (intra continental plate) [23]. Namun demikian, penelitian tersebut mengelompokkan batuan gunung api di Lampung dan Bengkulu ini berdasarkan letak, yaitu berada di barat dan di utara tanpa lebih rinci mengklasifikasi berdasarkan unit batuannya. Secara khusus, batuan gunung api di wilayah barat Lampung terpetakan dalam banyak satuan batuan, yaitu Formasi Kikim, Formasi Hulusimpang, Formasi Bal, Formasi Lakitan, Batuan Gunung Api Kuarter Tua, dan Batuan Gunung Api Kuarter Muda [24]. Jadi, belum ada studi yang membandingkan karakter geokimia antar unit batuan gunung api secara khusus.

Kabupaten Tanggamus berada di ujung selatan Lampung dengan morfologi umum terdiri dari dataran rendah, perbukitan bergelombang, pegunungan, dan kerucut gunung api (Gambar 1). Terdapat ragam batuan gunung api berumur Tersier hingga Kuarter di wilayah ini yang mungkin berkorelasi sehingga menarik untuk dikomparasi karakter geokimianya. Penelitian ini bertujuan untuk membandingkan 
komposisi geokimia batuan gunung api dari Formasi Hulusimpang berumur Tersier dengan batuan vulkanik Kuarter dari Gunung Tanggamus. Karakter geokimia dimanfaatkan untuk memprediksi proses pembentukan, mengkorelasikan dua kelompok batuan, dan memperkirakan mekanisme pengayaan UTJnya.

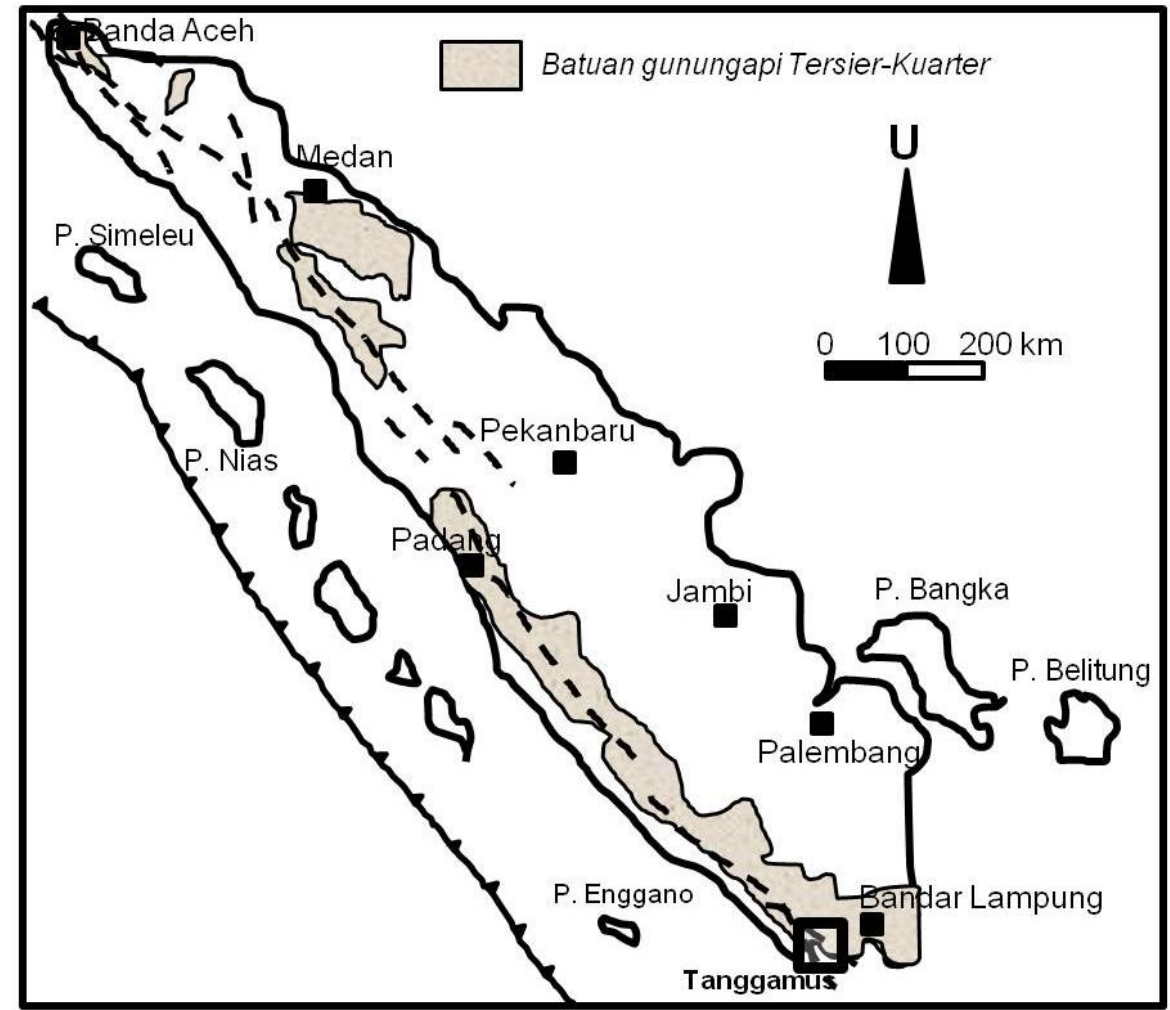

Gambar 1. Sebaran batuan gunung api Tersier hingga Kuarter di Sumatra [23]. Wilayah penelitian terdapat di ujung selatan Sumatra di sekitar Kabupaten Tanggamus.

\section{Geologi Lokal Tanggamus}

Geologi Kabupaten Tanggamus tersusun atas beberapa unit batuan gunung api, batuan intrusi, sedimen, dan endapan permukaan [24]. Sesar Sumatra (Great Sumatra Fault, GFT) sebagai suatu patahan yang memanjang dari Laut Andaman ke Selat Sunda berada di timur Kabupaten Tanggamus. Sesar ini sangat spesial karena $>45 \%$ gunung api aktif di Sumatra berada dalam radius $10 \mathrm{~km}$ [22]. Formasi Hulusimpang dan Formasi Gading yang keduanya terbentuk ketika OligosenMiosen adalah unit batuan tertua di Kabupaten Tanggamus. Kedua satuan batuan tersebut berhubungan menjari [24]. Formasi Hulusimpang tersusun atas breksi gunung api, lava, dan tuf dengan kisaran andesitik dan basal, sedangkan Formasi Gading terdiri dari batupasir, batulanau, dan batulempung dengan sisipan batugamping. Formasi Hulusimpang ini merupakan unit batuan dengan domain terluas di Kabupaten Tanggamus (Gambar 2).

Unit Batuan Terobosan terdiri dari granit, granodiorit, diorit, dan dasit yang diperkirakan terkristalisasi pada kala Miosen Tengah. Batuan terobosan tersebut kemungkinan merupakan batuan yang disebut sebagai Granit Lampung dengan hasil penanggalan radiometrik $8 \pm 0,1$ jtl [25] dan menerobos Formasi Hulusimpang [24]. Formasi Bal yang berumur Miosen Akhir tersingkap pada beberapa wilayah kecil dan relatif lebih felsik daripada Formasi 
Hulusimpang karena tersusun atas dasit, tuf dasitan, dan sisipan batupasir. Satuan Batuan Gunung Api Kuarter Muda di wilayah ini terutama bersumber dari Gunung Tanggamus yang terdiri dari breksi, lava, dan tuff dengan klasifikasi basal hingga andesit [24].

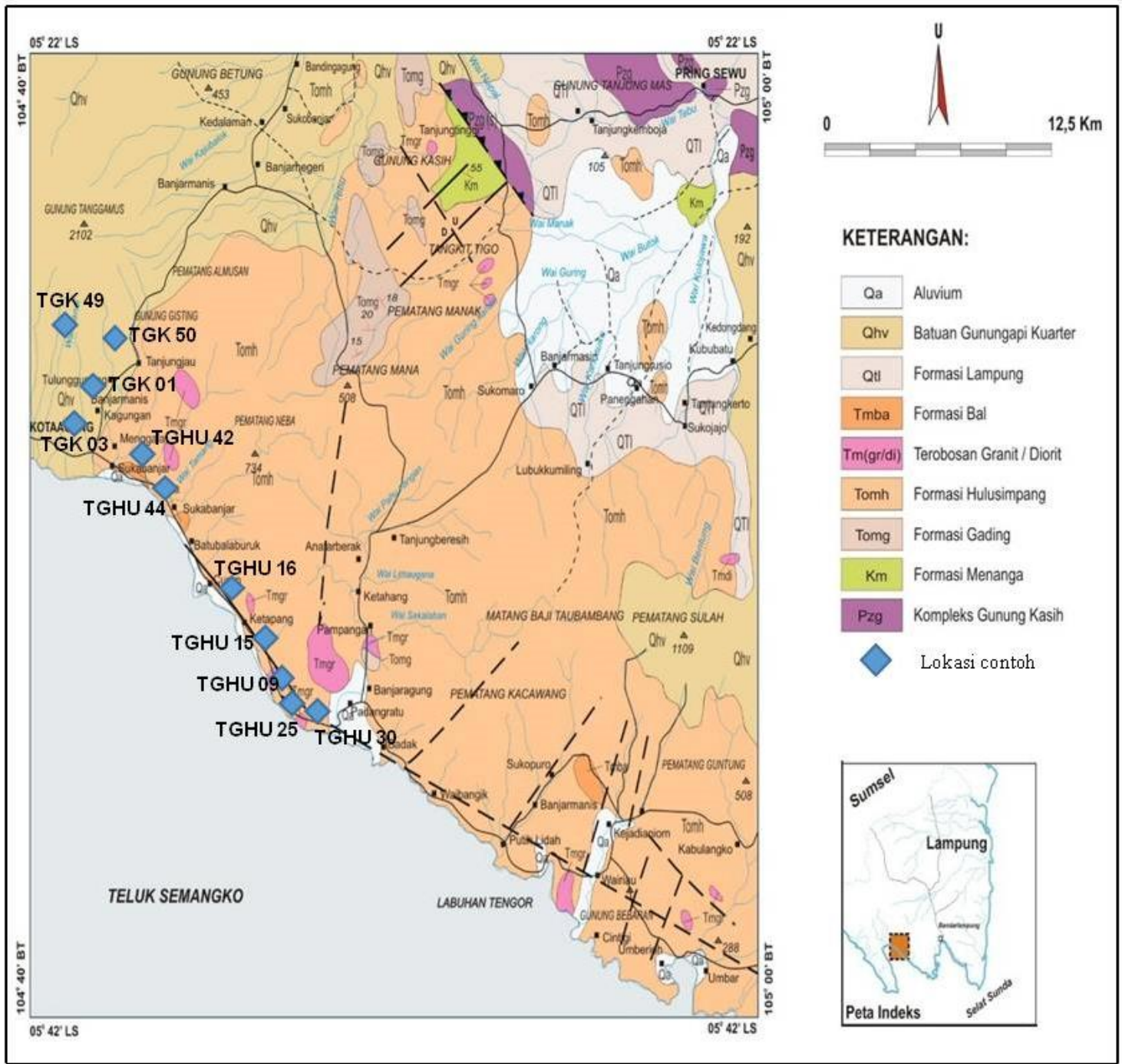

Gambar 2. Geologi lokal Kabupaten Tanggamus dan sekitarnya berikut lokasi pengambilan sampel (modifikasi [24]).

\section{METODOLOGI}

\section{Deskripsi Sampel}

Empat sampel batuan gunung api Kuarter dari Gunung Tanggamus diambil dari wilayah Batu Keramat (TGK 01 dan TGK 03), Gisting (TGK 49), dan Talang Sepuh (TGK 50) untuk diperiksa kandungan geokimianya. TGK 01 diambil dari singkapan lava yang diperkirakan berkomposisi andesitik berwarna abu-abu, padat, keras, pejal, dan membentuk kekar. Pada stasiun pengamatan TGK 03 dijumpai singkapan lava Kuarter dengan kedudukan menindih batuan gunung api lain yang diperkirakan bagian dari Formasi Hulusimpang. Secara megaskopis, TGK 49 tampak bersifat lebih mafik dari dua sampel sebelumnya karena relatif lebih gelap. Sampel tersebut diambil dari bawah jembatan antar desa dan terkekarkan. Singkapan batuan yang diperkirakan berkomposisi andesit hingga dasit (TGK 50) dapat dijumpai di sebuah perkebunan kopi pada wilayah Desa Way Halom. 
Studi geokimia kelompok batuan gunung api Formasi Hulusimpang berumur Tersier direpresentasikan oleh TGHU 09, TGHU 15, TGHU 16, TGHU 25 A, TGHU 30, TGHU 42, dan TGHU 44. Tiga sampel pertama diambil dari wilayah Ketapang yang secara umum berkomposisi basal hingga andesit berwarna abu-abu gelap, padat, dan pejal. Sampel TGHU 25 A dideskripsi sebagai batuan andesitik kelabu keabu-abuan, padat, pejal, dan diambil dari wilayah Limau dekat lokasi penambangan emas yang telah

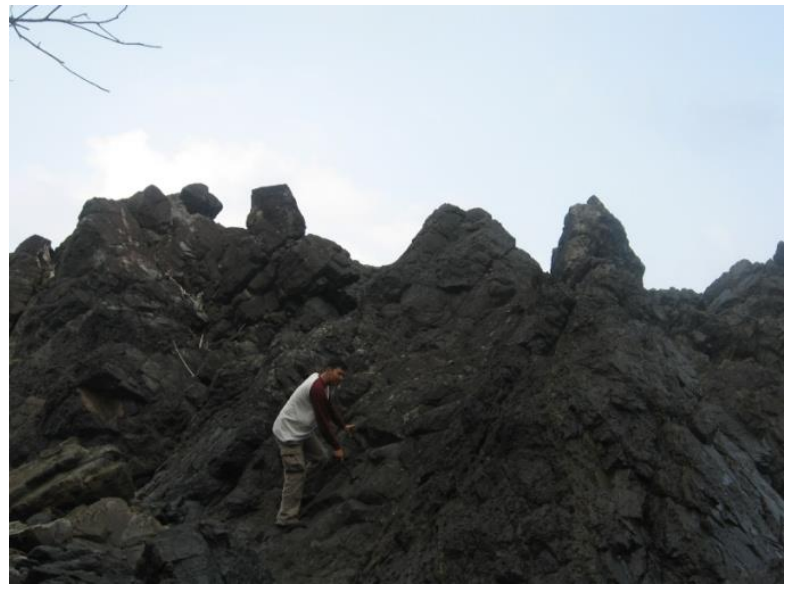

(a) ditinggalkan. Sebuah tebing lereng pebukitan di Desa Sukabanjar yang terbentuk dari batuan andesitik berwarna keabu-abuan di wilayah Limau adalah lokasi pengambilan sampel TGHU 30. TGHU 42 dan TGHU 44. Meskipun diambil dari lereng yang berbeda, kedua sampel ini tampak serupa sebagai fragmen andesitik yang telah terbreksikan berwarna kelabu dan cukup keras. Beberapa kondisi di lapangan dapat diperhatikan pada Gambar 3.

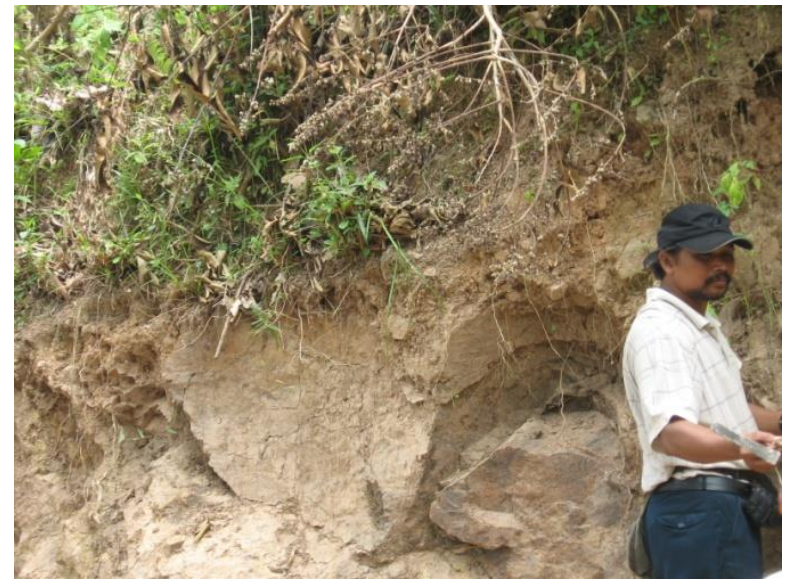

(b)

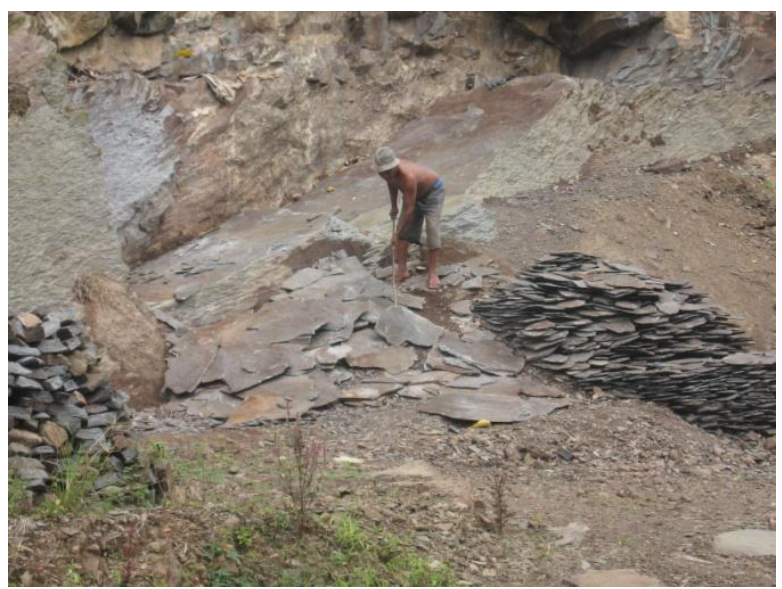

(c)

Gambar 3. Beberapa kondisi lapangan pada studi batuan gunung api di ujung selatan Sumatra: (a) TGHU 09 yang diambil dekat pesisir di Ketapang; (b) sampel TGHU 25 pada suatu longsoran di Limau; dan (c) dijumpai lava Kuarter maupun batuan gunung api Tersier di Batu Keramat pada lokasi TGK 03.

\section{Analisis Geokimia}

Seluruh sampel dikirim ke Laboratorium Pusat Survei Geologi untuk dipreparasi dan diuji kadar geokimianya menggunakan perangkat Advant XRF (X-Ray Fluorescence) dan X-Series Thermo ICP-MS (Inductively 
Coupled Plasma-Mass Spectrometry). Pengukuran dilakukan untuk mengetahui komposisi bulk sample. Seluruh batuan dicuci dan dipisahkan bagian-bagian lapuknya sebelum dikeringkan di luar ruangan selama setidaknya satu hari kerja. Batuan digerus dan ditumbuk hingga diperoleh besar butir -200 mesh. Penggerusan dimaksudkan untuk memudahkan proses preparasi dengan bahan kimia akibat perluasan bidang kontak. Analisis XRF dimanfaatkan untuk mengukur kadar oksida utama $\left(\mathrm{SiO}_{2}, \mathrm{TiO}_{2}, \mathrm{Al}_{2} \mathrm{O}_{3}\right.$, $\mathrm{Fe}_{2} \mathrm{O}_{3 \mathrm{~T}}, \mathrm{MnO}, \mathrm{CaO}, \mathrm{MgO}, \mathrm{K}_{2} \mathrm{O}$, dan $\mathrm{Na}_{2} \mathrm{O}$ ) dengan menggunakan teknik pressed pellet berdasarkan pertimbangan dan runtunan yang telah dijelaskan dalam studi terdahulu [3]. Pada sisi lain, kadar unsur jejak dan UTJ (Sc, $\mathrm{V}, \mathrm{Cr}, \mathrm{Rb}, \mathrm{Sr}, \mathrm{Y}, \mathrm{Zr}, \mathrm{Nb}, \mathrm{Cs}, \mathrm{Ba}, \mathrm{La}, \mathrm{Ce}, \mathrm{Pr}$, Nd, Sm, Eu, Gd, Tb, Dy, Ho, Er, Tm, Yb, Lu, dan $\mathrm{Pb}$ ) dianalisis menggunakan perangkat ICP-MS.

Pada preparasi pengujian kadar unsur jejak dan unsur tanah jarang, 1 gram sampel didestruksi menggunakan tiga asam kuat, yaitu $\mathrm{HCl}$ (asam klorat), $\mathrm{HF}$ (asam format), dan $\mathrm{HNO}_{3}$ (asam nitrat). Destruksi dilakukan di atas hotplate agar reaksi berjalan lebih cepat dan sempurna. Penambahan asam perklorat $\left(\mathrm{HClO}_{4}\right)$ diperlukan karena masih terdapat sampel yang belum terdestruksi sempurna menggunakan tiga asam tadi. Destruksi dihentikan setelah hampir seluruh pelarut kering akibat pemanasan. Larutan induk diperoleh dengan penambahan $\mathrm{HNO}_{3}$ $2 \%$ kepada sampel tersebut. Pada hari yang sama dengan pengukuran menggunakan ICP$\mathrm{MS}, 1 \mathrm{ml}$ larutan induk diencerkan dengan $\mathrm{HNO}_{3} \quad 2 \%$ hingga volume $10 \mathrm{ml}$. Dua certified reference materials, yaitu AGV-2 dan GBW 7113 dipreparasi melalui proses yang sama dengan sampel untuk mengkonfirmasi tingkat kebenaran analisis. Lima tingkat larutan kalibrasi dari setiap elemen yang diukur bermanfaat sebagai dasar perhitungan count per second (CPS) menjadi komposisi oleh perangkat ICP-MS.

\section{HASIL DAN PEMBAHASAN}

Rentang kandungan $\mathrm{SiO}_{2}$ sampel dari Formasi Hulusimpang pada studi ini jauh lebih lebar (49,89-67,04\%) daripada sampel Kuarter $(50,30-57,98 \%)$. Hal ini bermakna bahwa kelompok pertama berkisar antara batuan beku menengah (intermediate) hingga felsik, sedangkan kelompok kedua seluruhnya bertipikal intermediate. Oleh sebab itu, rentang oksida maupun unsur kimia pada batuan berumur Tersier tersebut juga cenderung lebih luas. Rerata $\mathrm{TiO}_{2}, \mathrm{Al}_{2} \mathrm{O}_{3}$, $\mathrm{Fe}_{2} \mathrm{O}_{3 \mathrm{~T}}, \mathrm{MnO}, \mathrm{CaO}, \mathrm{MgO}$ batuan Kuarter lebih besar bila dibandingkan dengan batuan Tersier. Pada sisi lain, total logam alkali sampel Formasi Hulusimpang lebih banyak daripada kelompok Kuarter dengan rerata jumlah $\mathrm{Na}_{2} \mathrm{O}+\mathrm{K}_{2} \mathrm{O}$ masing-masing 6,17\% dan $4,69 \%$ secara berurutan. Berdasarkan nilai LOI, batuan dari kelompok Kuarter dapat dikategorikan lebih segar daripada kelompok tersier. Sebelum diplot ke dalam beberapa diagram, komposisi oksida utama telah dinormalisasi untuk mendapatkan interpretasi yang sesuai.

Rerata kelimpahan beberapa unsur Light Ion Lithophile Elements (LILE), yaitu $\mathrm{Rb}, \mathrm{Sr}$, dan $\mathrm{Ba}$ berada dalam tingkat menengah. Meski demikian, terdapat kecenderungan bahwa batuan gunung api Kuarter lebih terkayakan kadar LILE-nya, terutama TGK 01 dan TGK 39. Fakta tersebut pararel dengan kemungkinan adanya kontaminasi kerak seperti pada batuan gunung api di Bengkulu dan Lampung [23]. Kelimpahan UTJ seluruh sampel cenderung pada tingkat rendah hingga menengah karena memang sebagian besar bukan merupakan batuan beku felsik yang telah terdiferensiasi jauh. Secara 
umum, kelompok sampel dari Formasi dengan rerata masing-masing 61,72 ppm dan Hulusimpang berkonsentrasi UTJ total lebih 46,10 ppm secara berurutan. Komposisi tinggi relatif terhadap kelompok Kuarter setiap sampel terangkum dalam Tabel 1.

Tabel 1. Konsentrasi geokimia bulk-sample pada studi ini.

\begin{tabular}{|c|c|c|c|c|c|c|c|c|c|c|c|}
\hline \multirow[b]{2}{*}{ Sampel } & \multicolumn{7}{|c|}{ Batuan Gunung api Formasi Hulusimpang (Tersier) } & \multicolumn{4}{|c|}{ Batuan Gunung api Kuarter } \\
\hline & $\begin{array}{c}\text { TGHU } \\
09 \\
\end{array}$ & $\begin{array}{c}\text { TGHU } \\
15 \\
\end{array}$ & $\begin{array}{c}\text { TGHU } \\
25 \\
\end{array}$ & $\begin{array}{c}\text { TGHU } \\
42 \\
\end{array}$ & $\begin{array}{c}\text { TGHU } \\
44\end{array}$ & $\begin{array}{c}\text { TGHU } \\
30 \\
\end{array}$ & $\begin{array}{c}\text { TGHU } \\
16 \\
\end{array}$ & $\begin{array}{c}\text { TGK } \\
01 \\
\end{array}$ & $\begin{array}{c}\text { TGK } \\
03 \\
\end{array}$ & $\begin{array}{c}\text { TGK } \\
50 \\
\end{array}$ & $\begin{array}{c}\text { TGK } \\
39 \\
\end{array}$ \\
\hline \multicolumn{12}{|c|}{ Oksida Utama (\%) } \\
\hline $\mathrm{SiO}_{2}$ & 49,89 & 62,23 & 57,65 & 52,20 & 49,44 & 63,79 & 67,04 & 57,44 & 57,98 & 50,30 & 52,01 \\
\hline $\mathrm{TiO}_{2}$ & 0,85 & 0,45 & 0,71 & 0,68 & 0,98 & 0,46 & 0,38 & 0,82 & 0,89 & 0,75 & 1,09 \\
\hline $\mathrm{Al}_{2} \mathrm{O}_{3}$ & 21,96 & 16,70 & 18,23 & 18,20 & 20,01 & 17,19 & 15,08 & 19,60 & 18,73 & 21,54 & 20,67 \\
\hline $\mathrm{Fe}_{2} \mathrm{O}_{3 \mathrm{~T}}$ & 8,56 & 3,75 & 6,59 & 7,14 & 8,21 & 5,35 & 2,78 & 7,17 & 7,91 & 9,70 & 8,97 \\
\hline $\mathrm{MnO}$ & 0,14 & 0,11 & 0,17 & 0,14 & 0,14 & 0,17 & 0,05 & 0,17 & 0,17 & 0,17 & 0,07 \\
\hline $\mathrm{CaO}$ & 4,54 & 4,56 & 5,78 & 7,88 & 8,40 & 3,24 & 3,00 & 6,27 & 5,99 & 8,51 & 8,72 \\
\hline $\mathrm{MgO}$ & 4,02 & 1,21 & 2,50 & 2,87 & 2,91 & 0,74 & 0,88 & 1,75 & 1,98 & 4,84 & 2,83 \\
\hline $\mathrm{Na}_{2} \mathrm{O}$ & 5,95 & 5,53 & 4,36 & 4,56 & 4,24 & 4,26 & 4,48 & 4,55 & 4,60 & 2,91 & 3,25 \\
\hline $\mathrm{K}_{2} \mathrm{O}$ & 0,52 & 1,23 & 1,97 & 1,63 & 0,81 & 2,39 & 1,27 & 1,06 & 0,98 & 0,56 & 0,83 \\
\hline $\mathrm{P}_{2} \mathrm{O}_{5}$ & 0,24 & 0,14 & 0,18 & 0,16 & 0,21 & 0,19 & 0,09 & 0,30 & 0,23 & 0,12 & 0,19 \\
\hline LOI & 2,77 & 3,45 & 1,75 & 3,85 & 4,10 & 1,59 & 4,17 & 0,29 & 0,15 & 0,11 & 0,89 \\
\hline \multicolumn{12}{|c|}{ Unsur Jejak dan Unsur Tanah Jarang (ppm) } \\
\hline $\mathrm{Sc}$ & 15,72 & 5,35 & 10,11 & 5,57 & 11,34 & 8,75 & 4,76 & 13,13 & 17,61 & 12,73 & 17,71 \\
\hline $\mathrm{V}$ & 155,82 & 39,54 & 100,48 & 46,56 & 92,37 & 13,51 & 53,82 & 54,88 & 84,38 & 245,00 & 240,52 \\
\hline $\mathrm{Cr}$ & 50,04 & 59,33 & 36,04 & 47,18 & 20,68 & 25,91 & 7,53 & 103,18 & 14,35 & 15,09 & 110,00 \\
\hline $\mathrm{Rb}$ & 15,41 & 23,96 & 41,76 & 41,46 & 28,44 & 31,23 & 31,70 & 29,61 & 18,66 & 17,27 & 28,82 \\
\hline $\mathrm{Sr}$ & 305,50 & 167,50 & 284,50 & 198,50 & 177,60 & 83,28 & 251,90 & 427,70 & 227,40 & 283,90 & 424,80 \\
\hline $\mathrm{Y}$ & 8,54 & 9,44 & 12,25 & 11,40 & 8,79 & 20,18 & 27,41 & 16,61 & 17,47 & 10,02 & 16,37 \\
\hline $\mathrm{Zr}$ & 21,02 & 47,75 & 78,64 & 83,21 & 46,26 & 42,77 & 70,81 & 53,15 & 45,47 & 80,60 & 120,31 \\
\hline $\mathrm{Nb}$ & 1,46 & 2,17 & 1,31 & 2,59 & 0,78 & 2,85 & 0,97 & 1,74 & 0,99 & 2,24 & 1,59 \\
\hline Cs & 0,71 & 0,41 & 1,73 & 2,90 & 2,71 & 0,51 & 1,32 & 0,77 & 0,27 & 2,23 & 0,69 \\
\hline $\mathrm{Ba}$ & 47,08 & 78,68 & 119,20 & 149,90 & 78,72 & 229,50 & 138,40 & 263,00 & 94,09 & 120,50 & 272,40 \\
\hline $\mathrm{La}$ & 5,65 & 10,60 & 8,59 & 9,50 & 4,43 & 16,31 & 25,67 & 8,46 & 5,50 & 5,94 & 8,08 \\
\hline $\mathrm{Ce}$ & 10,42 & 22,69 & 20,15 & 20,87 & 10,11 & 32,23 & 38,41 & 19,38 & 13,34 & 11,72 & 17,07 \\
\hline $\operatorname{Pr}$ & 1,38 & 2,58 & 2,44 & 2,33 & 1,32 & 4,01 & 5,72 & 2,17 & 1,82 & 1,54 & 1,86 \\
\hline $\mathrm{Nd}$ & 6,22 & 10,50 & 10,66 & 9,65 & 5,99 & 18,87 & 24,67 & 10,11 & 9,46 & 6,96 & 9,12 \\
\hline $\mathrm{Sm}$ & 1,57 & 2,07 & 2,28 & 2,00 & 1,52 & 4,29 & 5,54 & 2,48 & 2,42 & 1,89 & 2,45 \\
\hline $\mathrm{Eu}$ & 0,52 & 0,53 & 0,69 & 0,59 & 0,51 & 1,07 & 1,41 & 1,05 & 0,95 & 0,70 & 0,88 \\
\hline $\mathrm{Gd}$ & 1,46 & 1,76 & 2,03 & 1,78 & 1,28 & 3,65 & 5,35 & 2,37 & 2,32 & 1,62 & 2,20 \\
\hline $\mathrm{Tb}$ & 0,30 & 0,31 & 0,35 & 0,35 & 0,26 & 0,69 & 1,00 & 0,57 & 0,51 & 0,38 & 0,50 \\
\hline Dy & 1,73 & 1,62 & 2,15 & 1,93 & 1,51 & 3,92 & 5,86 & 2,93 & 3,13 & 1,95 & 2,62 \\
\hline Ho & 0,38 & 0,30 & 0,46 & 0,38 & 0,34 & 0,79 & 1,24 & 0,72 & 0,67 & 0,47 & 0,63 \\
\hline $\mathrm{Er}$ & 0,82 & 0,72 & 1,20 & 1,03 & 0,82 & 2,02 & 3,26 & 1,83 & 1,80 & 1,07 & 1,62 \\
\hline $\mathrm{Tm}$ & 0,15 & 0,10 & 0,19 & 0,18 & 0,13 & 0,27 & 0,51 & 0,36 & 0,28 & 0,24 & 0,29 \\
\hline $\mathrm{Yb}$ & 0,76 & 0,60 & 1,27 & 1,10 & 0,84 & 1,69 & 3,30 & 1,90 & 1,95 & 1,11 & 1,76 \\
\hline $\mathrm{Lu}$ & 0,11 & 0,09 & 0,19 & 0,16 & 0,11 & 0,23 & 0,52 & 0,37 & 0,32 & 0,23 & 0,33 \\
\hline $\mathrm{Pb}$ & 0,56 & 3,47 & 6,45 & 3,65 & 1,20 & 0,51 & 1,74 & 29,97 & 6,58 & 1,00 & 28,58 \\
\hline
\end{tabular}


Berdasarkan diagram total alkali versus silika [26], sampel dari Formasi Hulusimpang dapat diklasifikasikan menjadi basaltik trakiandesit (tiga sampel), trakiandesit (satu sampel), dasit (dua sampel), dan riolit (satu sampel). Penggunaan diagram yang sama menunjukkan bahwa batuan gunung api Kuarter dari daerah paling selatan Sumatra ini dikategorikan sebagai basal, basaltik-andesit, dan andesit yang masing-masing terdiri dari satu, satu, dan dua sampel secara berurutan

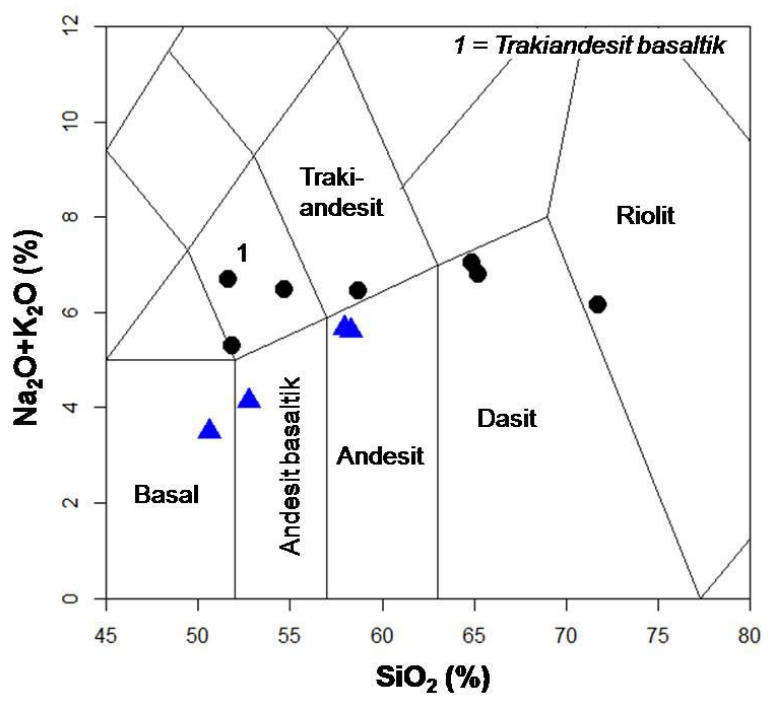

(a)
(Gambar 4a). Seluruh sampel merupakan batuan seri kalk-alkali dengan mengacu pada diagram perbandingan komposisi $\mathrm{SiO}_{2}$ terhadap konsentrasi $\mathrm{K}_{2} \mathrm{O}$ seperti dapat dilihat pada Gambar 4b. Meskipun sebagian besar batuan bersifat metalumina (Gambar 4c), terdapat satu sampel Kuarter dan dua sampel Tersier yang merupakan kelompok peralumina akibat dominansi komposisi aluminium terhadap jumlah kalsium dan alkali.

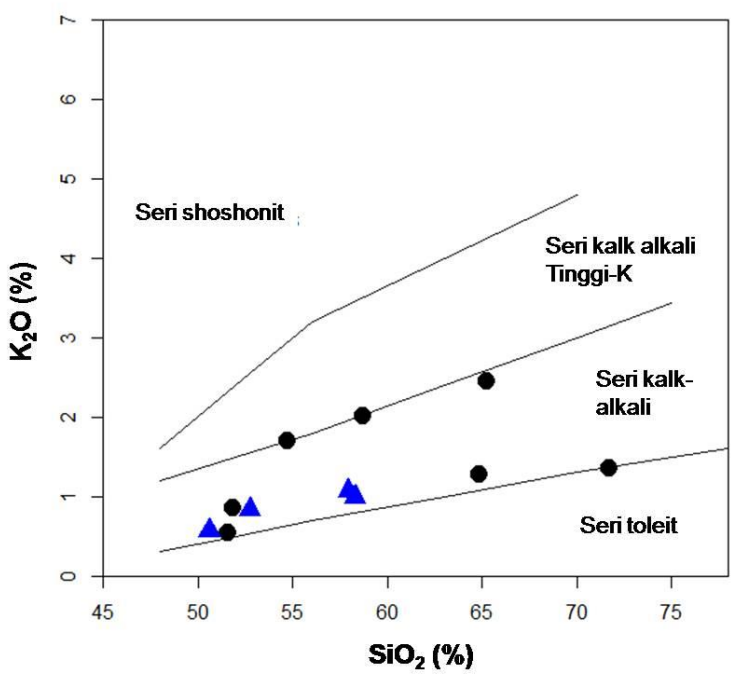

(b)

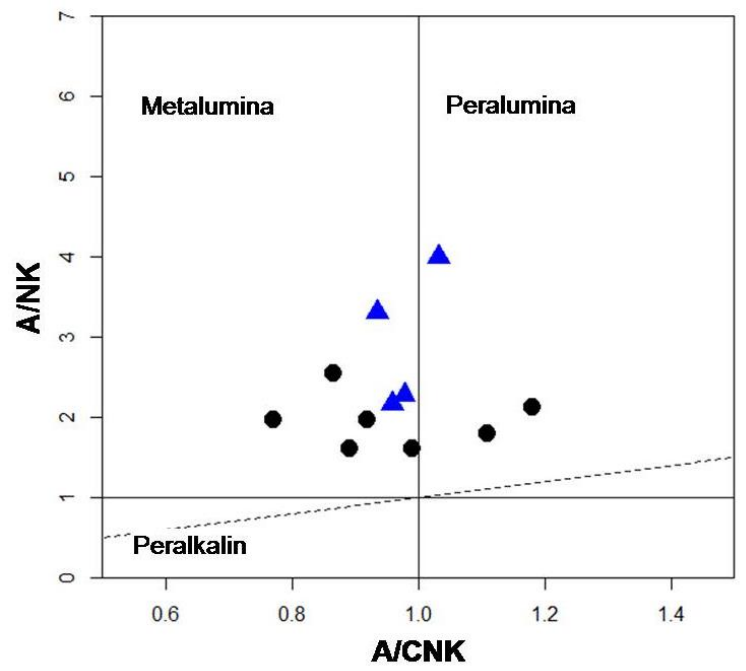

(c)

Gambar 4.(a) Sampel yang dipelajari berada pada rentang basal hingga riolit berdasarkan diagram total alkali vesus silika [26]; (b) Seluruh sampel berada dalam seri kalk-alkalin berdasarkan perbandingan $\mathrm{SiO}_{2}$ terhadap $\mathrm{K}_{2} \mathrm{O}$; dan (c) Meskipun sebagian besar batuan yang dipelajari berkarakter metalumina, terdapat beberapa yang dikategorikan peralumina. $=$ batuan gunung api Tersier dan $\Delta=$ sampel Kuarter. 
Studi ini membuktikan adanya keberadaan andesit di sekitar Kabupaten Tanggamus yang sebelumnya tidak terdapat pada studi terdahulu [23] sehingga menunjukkan kemungkinan adanya proses diferensiasi magma. Namun demikian, kontaminasi kerak masih dapat terdeteksi melalui beberapa sampel yang berkarakter peralumina kuat [27]. Beberapa sampel berkonsentrasi LILE tinggi memperjelas kemungkinan keterdapatan kontaminasi. Beberapa korelasi $\mathrm{SiO}_{2}$ yang kurang sempurna terhadap oksida utama lainnya sangat mungkin disebabkan oleh kontaminasi kerak heterogen ketika magma naik [27].

Diagram Harker sering digunakan untuk menjelaskan proses diferensiasi magma maupun korelasi antar batuan [3, 5, 9, 28, 29]. Korelasi negatif $\mathrm{SiO}_{2}$ terhadap $\mathrm{TiO}_{2}, \mathrm{Al}_{2} \mathrm{O}_{3}$, $\mathrm{Fe}_{2} \mathrm{O}_{3} \mathrm{~T}, \mathrm{CaO}$, dan $\mathrm{MgO}$ ditunjukkan oleh kedua kelompok batuan gunung api (Gambar 5). Penurunan konsentrasi $\mathrm{Al}_{2} \mathrm{O}_{3}, \mathrm{CaO}$, dan $\mathrm{MgO}$ seiring dengan kenaikan kadar $\mathrm{SiO}_{2}$ dapat disebabkan oleh fraksionasi plagioklas. Kristalisasi ilmenit mungkin menjadi penyebab korelasi negatif $\mathrm{Fe}_{2} \mathrm{O}_{3} \mathrm{~T}$ dan $\mathrm{TiO}_{2}$ terhadap $\mathrm{SiO}_{2}$. Kelimpahan $\mathrm{Na}_{2} \mathrm{O}, \mathrm{K}_{2} \mathrm{O}$, dan $\mathrm{P}_{2} \mathrm{O}_{5}$ tampak meningkat dengan kenaikan jumlah $\mathrm{SiO}_{2}$ pada sampel Kuarter. Meskipun $\mathrm{P}_{2} \mathrm{O}_{5}$ cenderung menurun dengan peningkatan $\mathrm{SiO}_{2}$ pada batuan Tersier, tidak terdapat korelasi yang jelas antara $\mathrm{Na}_{2} \mathrm{O}$ dan $\mathrm{SiO}_{2}$ pada kelompok ini. Walaupun adanya beberapa perbedaan tren pada diagram Harker tersebut, besar kemungkinan bahwa kedua kelompok ini secara petrogenesis berasal dari magma yang sama dengan mengacu pada overlapping dalam sebagian besar kurva seperti dijelaskan oleh beberapa studi terdahulu [3, 30, 31].

Perbedaan berikutnya dari kedua kelompok ini adalah korelasi positif $\mathrm{SiO}_{2}$ dan total UTJ yang sangat kuat pada batuan dari
Formasi Hulusimpang. Pada sisi lain, jumlah UTJ pada batuan Kuarter tampak sangat dipengaruhi oleh mineral fosfat berdasarkan indikasi kenaikan jumlah UTJ terhadap konsentrasi $\mathrm{P}_{2} \mathrm{O}_{5}$ dengan koefisein korelasi (r) 0,88 . Seluruh data komposisi UTJ dinormalisasi terhadap konsentrasi chondrite [32] untuk menghilangkan efek OddoHarkins dan memudahkan interpretasi selanjutnya. Kedua jenis batuan gunung api menunjukkan penurunan curam pada UTJringan. Namun demikian, UTJ-berat pada kelompok sampel Kuarter relatif lebih landai daripada kelompok lain. Perbandingan diagram laba-laba konsentrasi UTJ yang telah dinormalisasi terhadap chondrite terlampir pada Gambar 6.

Seluruh sampel dari kelompok Kuarter menunjukkan anomali Eu positif sedangkan batuan dari Formasi Hulusimpang cenderung tanpa anomali hingga beranomali Eu negatif. Secara matematis, besaran anomali $\mathrm{Eu}$ dihitung berdasarkan persamaan (1) [7, 9]:

$$
E u / E u^{*}=\frac{E u_{N}{ }^{2}}{S m_{N} \times G d_{N}}
$$

Anomali Eu positif ditandai dengan $\mathrm{Eu} / \mathrm{Eu}^{*}>1$ sedangkan anomali negatif jika $\mathrm{Eu} / \mathrm{Eu}^{*}<1$. Nilai $\mathrm{Eu}_{\mathrm{N}}, \mathrm{Sm}_{\mathrm{N}}$, dan $\mathrm{Gd}_{\mathrm{N}}$ adalah hasil normalisasi europium, samarium, dan gadolinium terhadap nilai chondrite-nya. Studi sebelumnya menyebut bahwa proporsi yang cukup antara plagioklas dan amfibol dapat menekan derajat anomali $\mathrm{Eu}$ [1] sedangkan sumber magma kaya plagioklas maupun adisi plagioklas selama proses pembentukan batuan dapat menyebabkan anomali Eu positif [3, 7, 31]. Pada sampel dari Formasi Hulusimpang dalam studi ini $\mathrm{Eu} / \mathrm{Eu}^{*}$ berkorelasi negatif terhadap $\mathrm{SiO}_{2}(\mathrm{r}=$ $-0,86)$ dan berkorelasi positif terhadap $\mathrm{CaO}(\mathrm{r}$ $=0,74$ ) sehingga sangat mungkin telah terjadi pengurangan plagioklas, terutama plagioklas 
Ca selama proses pembentukan batuan. Pada sisi lain, tidak terdapat korelasi yang kuat antara $\mathrm{Eu} / \mathrm{Eu}^{*}$ terhadap $\mathrm{SiO}_{2}$ pada sampel
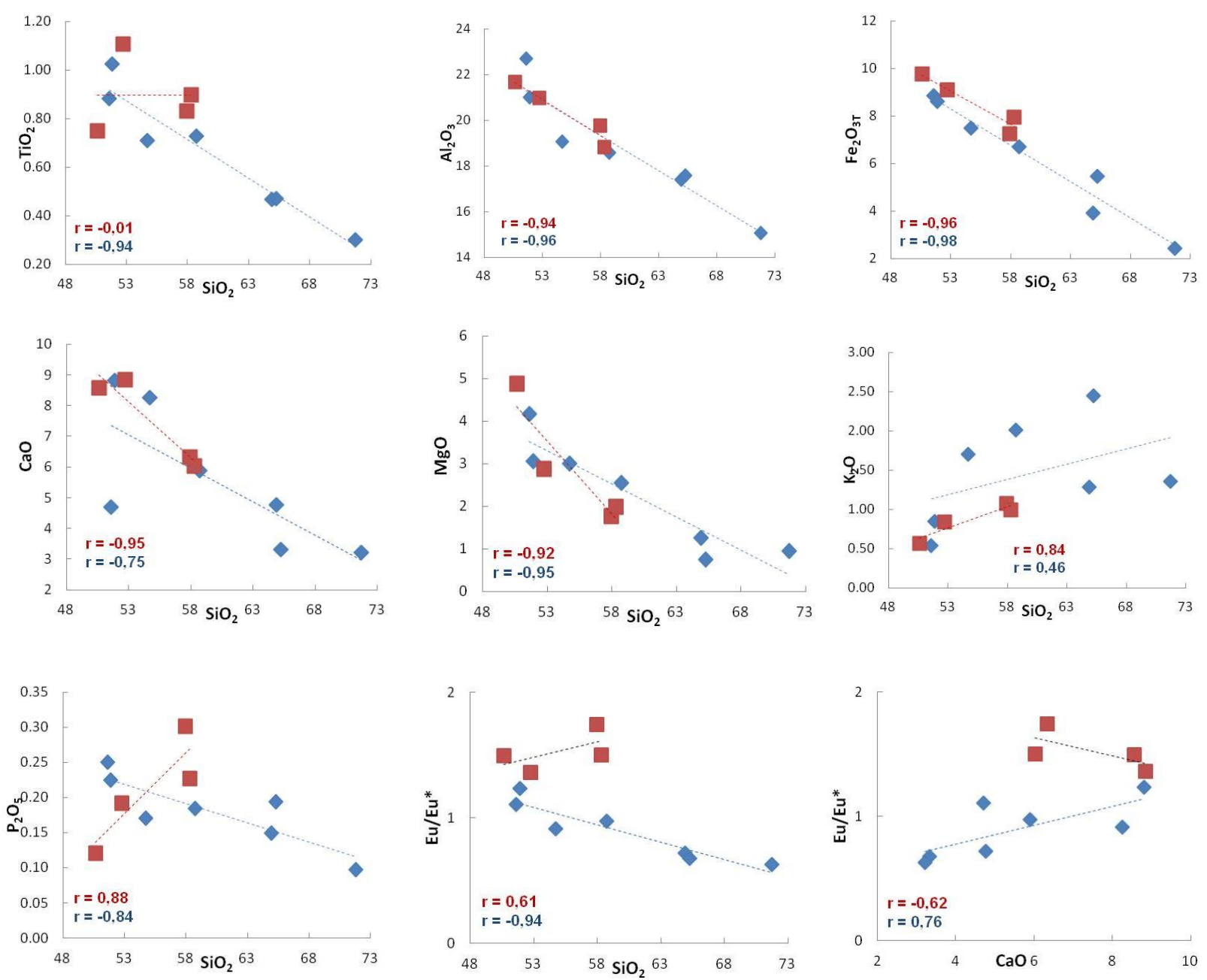

Gambar 5. Diagram biner oksida utama terhadap $\mathrm{SiO}_{2}$ berikut trendline dan koefisien korelasinya. Kecenderungan yang sama dapat diperhatikan pada hampir seluruh diagram, kecuali $\mathrm{SiO}_{2}$ versus $\mathrm{P}_{2} \mathrm{O}_{5}$ dan $\mathrm{SiO}_{2}$ versus Eu/Eu*. = batuan gunung api Tersier dan $\boldsymbol{\omega}=$ sampel Kuarter.

(a)

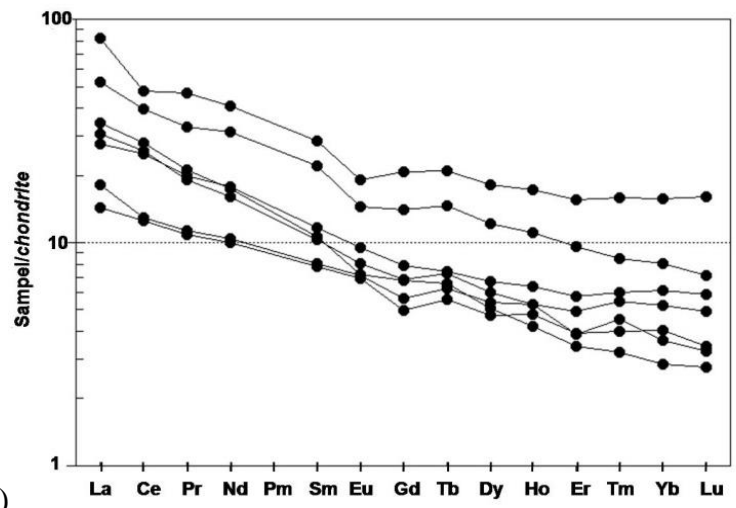

(b)

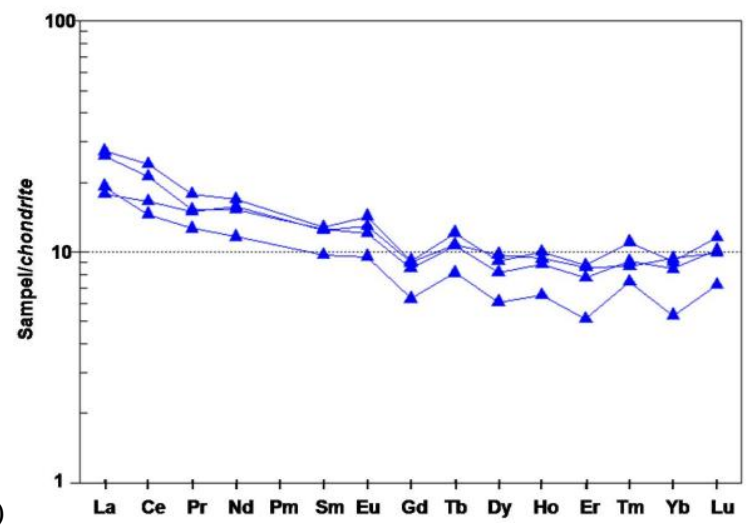

Gambar 6. Diagram laba-laba UTJ kedua kelompok batuan setelah normalisasi terhadap konsentrasi chondrite [32]: (a) batuan gunung api Formasi Hulusimpang; dan (b) batuan gunung api Kuarter. Perbedaan terdapat pada kemiringan kurva UTJ-berat dan kecenderungan anomali Eu. 


\section{KESIMPULAN}

Batuan gunung api Tersier dari Formasi Hulusimpang di wilayah Kabupaten Tanggamus dan sekitarnya memiliki rentang trakiandesit basaltik hingga riolit, berada dalam seri kalk-alkali, dan berkarakter metalumina-peralumina. Meskipun samasama berada dalam seri kalk-alkali, batuan gunung api Kuarter bertipikal basal hingga dasit dan cenderung metalumina. Diagram Harker membuktikan bahwa kedua kelompok sampel berasal dari sumber magma yang sama yang telah mengalami diferensiasi. Indikasi adanya kontaminasi dapat disimpulkan dari keterdapatan batuan peralumina, komposisi LILE tinggi pada beberapa sampel, dan gangguan pada diagram Harker. Perbedaan karakter kedua kelompok sampel diperjelas pada diagram normalisasi UTJ, yaitu derajat kemiringan kurva UTJberat dan kecenderungan anomali Eu. Studi ini selanjutnya dapat diperkuat oleh pemeriksaan mikroskopis maupun analisis geokimia mineral.

\section{UCAPAN TERIMA KASIH}

Penulis menyampaikan terimakasih kepada Kepala Pusat Survei Geologi atas izin publikasinya. Pembiayaan studi ini berasal dari Kelompok Kerja Wilayah Lampung di Bidang Sarana Penelitian - Pusat Survei Geologi. Bapak Sigit Maryanto dan Bapak Joko Subandrio telah mengarahkan penulis mengenai pemanfaatan data geokimia. Bapak Kurnia, Bapak Usep, dan Ibu Erna telah membantu penulis untuk memperoleh hasil analisis laboratorium yang presisi dan akurat.

\section{DAFTAR PUSTAKA}

[1] Y. Eyuboglu, M. Santosh, dan S.L. Chung, "Crystal Fractionation of Adakitic Magmas in the Crust-Mantle Transition Zone: Petrology, Geochemistry and U-Pb Zircon Chronology of the Seme Adakites, Eastern Pontides, NE Turkey," Lithos, 121(1-4), 151-166, 2011, doi: 10.1016/j.lithos.2010.10.012.

[2] R.R. Almeev, J.I. Kimura, A.A. Ariskin, dan A.Y. Ozerov, "Decoding Crystal Fractionation in Calc-Alkaline Magmas from the Bezymianny Volcano (Kamchatka, Russia) using Mineral and Bulk Rock Compositions", Journal of Volcanology and Geothermal Research,263, 141-171, 2013, doi: 10.1016/j.jvolgeores.2013.01.003.

[3] R. Irzon, "Comagmatic Andesite and Dacite in Mount Ijo, Kulonprogo: A Geochemistry Perspective," Jurnal Geologi dan Sumberdaya Mineral, 19(4), 221-231, 2018, doi: 10.33332/jgsm.geologi.v19i4.185.

[4] B. Tuller-Ross, P. S. Savage, H. Chen, dan K Wang, "Potassium Isotope Fractionation during Magmatic Differentiation of Basalt to Rhyolite," Chemical Geology, 525, 37-45, 2019, doi: 10.1016/j.chemgeo.2019.07.017.

[5] K. S. Widana, dan B. Priadi, "Karakteristik Unsur Jejak Dalam Diskriminasi Magmatisme Granitoid Pulau Bangka," Eksplorium, 36(1), 116, 2015, doi: 10.17146/eksplorium.2015.36.1. 2766.

[6] I. Zulkarnain, "Sumatra is not a Homogenous Segment of Gondwana Derived Continental Blocks: A New Sight based on Geochemical Signatures of Pasaman Volcanic in West Sumatera," RISET Geologi dan Pertambangan, 26(1), 1-13, 2016, doi: 10.14203/risetgeotam2016.v26.271.

[7] R. Irzon, I. Syafri, A. A. Ghani, A. Prabowo, J. Hutabarat, dan P. Sendjaja, "Petrography and Geochemistry of the Pinkish Lagoi Granite, Bintan Island: Implication to Magmatic Differentiation, Classification, and Tectonic History," Bulletin of the Geological Society of Malaysia, 69, 27-37, 2020, doi: 10.7186/bgsm69202003.

[8] A. Bani, G. Echevarria, E. Montargès-Pelletier, F. Gjoka, S. Sulejman, dan J. L. Morel, "Pedogenesis and Nickel Biogeochemistry in a Typical Albanian Ultramafic Toposequence," Environmental Monitoring and Assessment, 187(7), 4431-4442, 2014, doi: 10.1007/s10661-014-3709-6.

[9] R. Irzon dan B. Abdullah, "Element Mobilization During Weathering Process of Ultramafic 
Complex in North Konawe Regency, Southeast Sulawesi Based on A Profile from Asera," Indonesian Journal on Geoscience, 5(3), 277-90, 2018, doi: 10.17014/ijog.5.3.277-290.

[10] E. H. Suryawan, A. Hilyah, M. H. M. Fajar, dan A. Pajrin, "Identifikasi dan Penentuan Volume Endapan Nikel Laterit Berdasarkan Data Geolistrik Metode Sounding Studi Kasus Blok Selatan Daerah Pomalaa, Sulawesi Tenggara," Jurnal Geosaintek, 5(2), 53-60, 2019, doi: 10.12962/j25023659.v5i2.5393.

[11] Z. Azadbakht, D. R. Lentz, C. R. M. McFarlane, dan J. B. Whalen, "Using Magmatic Biotite Chemistry to Differentiate Barren and Mineralized Silurian-Devonian Granitoids of New Brunswick, Canada," Contributions to Mineralogy and Petrology, 175(7), 1-24, 2020, doi: 10.1007/s00410-020-01703-2.

[12] H. Yilmaz, F. N. Sonmez, dan E. J. M. Carranza, "Discovery of $\mathrm{Au}-\mathrm{Ag}$ Mineralization by Stream Sediment and Soil Geochemical Exploration in Metamorphic Terrain in Western Turkey," Journal of Geochemical Exploration, 158, 55-73, 2015, doi: 10.1016/ j.gexplo.2015.07.003.

[13] R. Irzon, "Thorium and Total REE Correlation in Stream Sediment Samples from Lingga Regency," Eksplorium, 39(1), 1-16, 2018, doi: 10.17146/eksplorium.2018.39.1.3558.

[14] M. L. Benhaddya dan M. Hadjel, "Spatial Distribution and Contamination Assessment of Heavy Metals in Surface Soils of Hassi Messaoud, Algeria," Environmental Earth Sciences, 71(3), 1473-1486, 2014, doi: 10.1007/s12665-013-2552-3.

[15] R. Irzon, I. Syafri, J. Hutabarat, P. Sendjaja, dan S. Permanadewi, "Heavy Metals Content and Pollution in Tin Tailings from Singkep Island, Riau, Indonesia," Sains Malaysiana, 47(11), 2609-2616, 2018, doi: 10.17576/jsm-2018-471103.

[16] A. J. Barber dan M. J. Crow, "Structure of Sumatra and its Implications for the Tectonic Assembly of Southeast Asia and the Destruction of Paleotethys," Island Arc, 18(1), 3-20, 2009, doi: 10.1111/j.1440-1738.2008.00631.x.

[17] I. Metcalfe, "Tectonic Evolution of Sundaland," Bulletin of the Geological Society of Malaysia, 63, 27-60, 2017, doi: 10.7186/bgsm63201702.

[18] M. J. Salisbury, J. R. Patton, A. J. R Kent, C. Goldfinger, Y. Djadjadihardja, dan U. Hanifa, "Deep-Sea Ash Layers Reveal Evidence for
Large, Late Pleistocene and Holocene Explosive Activity from Sumatra, Indonesia," Journal of Volcanology and Geothermal Research,231232, 61-71, 2012, doi: 10.1016/j.jvolgeores. 2012.03.007.

[19] J. Stimac, A. M. Sihotang, W. Mussofan, M. Baroek, C. Jones, J. N. Moore, dan A. K. Schmitt, "Geologic Controls on the Muara Laboh Geothermal System, Sumatra, Indonesia," Geothermics, 82, 97-120, 2019, doi: 10.1016/j.geothermics.2019.06.002.

[20] S. Liu, I. Suardi, M. Zheng, D. Yang, X. Huang, dan P. Tong, "Slab Morphology Beneath Northern Sumatra Revealed by Regional and Teleseismic Traveltime Tomography," Journal of Geophysical Research: Solid Earth, 124(10), 10544-10564, 2019, doi: 10.1029/ 2019JB017625.

[21] A. J. Barber, "The origin of the Woyla Terranes in Sumatra and the Late Mesozoic Evolution of the Sundaland Margin," Journal of Asian Earth Sciences, 18(6), 713-738, 2000, doi: 10.1016/S1367-9120(00)00024-9.

[22] V. Acocella, O. Bellier, L. Sandri, M. Sébrier, dan S. Pramumijoyo, "Weak Tectono-Magmatic Relationships along an Obliquely Convergent Plate Boundary: Sumatra, Indonesia," Frontiers in Earth Science, 6, 3, 2018, doi: 10.3389/feart.2018.00003.

[23] I. Zulkarnain, "Petrogenesis Batuan Vulkanik Daerah Tambang Emas Lebong Tandai, Provinsi Bengkulu, Berdasarkan Karakter Geokimianya," Jurnal Geologi Indonesia, 3(2), 57-73, 2008, doi: 10.17014/ijog.vol3no2.20081.

[24] T. C. Amin, Sidarto, S. Santosa, dan W. Gunawan, "Peta Geologi Lembar Kotaagung, Sumatra," Bandung: Pusat Penelitian dan Pengembangan Geologi, 1993.

[25] A. J. Barber, M. J. Crow, dan J. Milsom (Eds.), Sumatra: Geology, Resources and Tectonic Evolution, London: Geological Society, 2005.

[26] E. A. K. Middlemost, "Naming Materials in the Magma/Igneous Rock System," Earth-Science Reviews, 37(3-4), 215-224, 1994, doi: 10.1016/0012-8252(94)90029-9.

[27] M. H. Roselee, A. A. Ghani, dan M. R. Umor, "Petrology and Geochemistry of Igneous Rocks from Southern Tioman Island, Pahang, Peninsular Malaysia," Bulletin of the Geological Society of Malaysia, 62, 79-89, 2016, doi: 10.7186/bgsm62201611. 
[28] K. S. Widana, "Petrografi dan Geokimia Unsur Utama Granitoid Pulau Bangka: Kajian Awal Tektonomagmatisme," Eksplorium, 34(2), 75-88, 2013, doi: 10.17146/eksplorium.2013.34.2.708.

[29] G. Abdul-Jabbar, H. Rachmat, dan M. Nakagawa, "Temporal Change of Barujari Volcano Magmatic Process: Inferred from Petrological Study of Erupted Products Since AD 1944," Journal of Physics: Conference Series, 1363(1), 012030, 2019, doi: 10.1088/1742-6596/1363/1/012030.

[30] A. K. El-Shazly, D. D. Sanderson, dan J. Napier, "Petrogenesis of I-type Granitoids from the Melrose Stock, East-Central Nevada," International Geology Review, 53(13),
1522-1558, 2011, doi: 10.1080/ 00206811003755396.

[31] R. Irzon, "Contrasting Two Facies of Muncung Granite in Lingga Regency Using Major, Trace, and Rare Earth Element Geochemistry," Indonesian Journal on Geoscience, 2(1), 23-33, 2015, doi: 10.17014/ijog.2.1.23-33.

[32] W. V. Boynton, "Cosmochemistry of the Rare Earth Elements: Meteorite Studies," Developments in Geochemistry, 2, 63-114, 1984, doi: 10.1016/B978-0-444-42148-7.50008-3. 
